\title{
Realising the Good University: Social Innovation, Care, Design Justice and Educational Infrastructure
}

\author{
Peter Goodyear ${ }^{1}$ (D)
}

Accepted: 3 August 2021 / Published online: 9 September 2021

(c) The Author(s), under exclusive licence to Springer Nature Switzerland AG 2021

\begin{abstract}
This paper is a contribution to the collective work of imagining better universities. It starts from Raewyn Connell's account of the good university, and develops four main ideas. Connell's insistence on thinking about universities as real workplaces, with real workforces doing real work that has real consequences, provides a disciplining foundation. On this basis, we must acknowledge that although changes are often set in motion outside a university, their realisation always depends on the work of university staff and students. Secondly, research on learning and teaching and the spaces in which they unfold can contribute to real change by providing stronger concepts and clearer language in which to imagine, discuss and plan. Thirdly, course and curriculum redesign, oriented to the great challenges that our students will be tackling in the next few decades, would benefit from an infusion of practices and values from the fields of social innovation and participatory design, and that design for social innovation needs a grounding in design justice. Finally, I outline some of the implications that we can infer for better learning spaces - understood from both a postdigital and a postcritical perspective. A connecting theme within this exploration is the realisation of care as thoughtful work.
\end{abstract}

Keywords University education · Social innovation · Care · Design justice · Learning Spaces $\cdot$ Educational infrastructure

\section{Introduction}

'Mind is care in the sense of solicitude - as well as active looking after things that need to be tended.' (Dewey 1958: 263)

Peter Goodyear

peter.goodyear@sydney.edu.au

1 CRLI, Sydney School of Education \& Social Work, The University of Sydney, Building A35, Sydney, Australia 
' $\ldots$ a politics of care engages much more than a moral stance; it involves affective, ethical, and hands-on agencies of practical and material consequence.' (Puig de la Bellacasa 2017: 4)

'What new purposes for the university might we imagine if we understand its role to be not inculcating state citizens, nor training corporate citizens, but instead facilitating the development of diverse, open communities - both on their campuses and across borders - encouraged to think together, to be involved in the ongoing project of how we understand and shape our world?' (Fitzpatrick 2019: 44-5)

This paper takes its title from Raewyn Connell's book The Good University (2019). Connell encourages us to consider universities as real working organisations with real workforces: to avoid being seduced by abstractions about what a university is, could and should be. She identifies five characteristics that mark out 'the good university' - that it is democratic, engaged, truthful, creative and sustainable. The main contribution of the current paper is to forge connections between these characteristics, curriculum redesign and university infrastructure. Imaginative, forwardmoving educational work needs to be done to realise better opportunities and spaces for learning. Geoff Mulgan (2020) reminds us that social science has a long tradition of exploring better futures: a tradition that has been partially eclipsed by the allure of critique. Like many, he sees the Covid-19 pandemic as a spur to thinking again about what is changeable and worth changing.

The crisis has forced actions that were scarcely imaginable six months ago. Could we use the crisis to rethink systems that are no longer fit for purpose, and discard zombie orthodoxies that have outlived their usefulness? And could we rekindle a forward-looking social science that combines rigour and imagination? (Mulgan 2020)

Sasha Costanza-Chock (2020) describes 'speculative design' as a method for collaboratively imagining, and bringing into being, capacious realities in which many future worlds can co-exist. Likewise, Maria Puig de la Bellacasa (2017: 7) speaks of the speculative as 'provoking political and ethical imagination in the present'. Speculative thinking of this kind can be found in the literature of (digital) higher education (e.g. Ross 2016), but it is still rather rare. The steps that I want to take here involve identifying conceptual resources that can help people who work in universities realise connections between locally plausible near-term actions and more distal aims and valued futures. Linking the micro and the macro is intellectually demanding work, when done co-operatively.

Connell is careful to argue that no single university can be all things to all people; nor can it rise to every challenge. Networks of co-operating, rather than antagonistic and competitive, universities are needed if we are to succeed with finding just transitions to more sustainable ways of living, including through responding honestly and effectively to demands for restorative action, decolonisation and dismantling the machineries that reproduce privilege and entrench disadvantage. 
Only a system organized for cooperation will allow specialization, division of labour, regional and institutional diversity, and sharing of facilities, without universities having to fear they will lose status or money. (Connell 2019: 175)

Moreover, each university needs to be several things to many people, offering congenial spaces for diverse communities, networks and groups, with distinctive but overlapping needs and interests.

The university systems that I know best — in the UK and Australia - have implemented many substantial changes over the last four decades. I draw on two of them here, relating to digital technologies and graduate employability. The rapid switch to 'emergency remote teaching' in the early months of the Covid-19 pandemic (Hodges et al. 2020; Rapanta et al. 2020; Lamb and Ross 2021) punctured the idea that university teachers are resistant to change and unwilling to use technology in teaching. Before Covid-19, increasing use of technologies such as 'lecture capture' was already raising questions about whether, how and why students value on-campus teaching. The possibility and speed of change has highlighted the fragility of apparently engrained practices and revealed their dependence on expectations about social and technical arrangements that are no longer stable. In a similar vein, the work done on graduate employability proves that universities can succeed in large-scale course, curriculum and assessment redesign, when the need arises. So there is reason to believe that more can be done, if, for example, we move beyond employability to also consider the wider sets of capabilities needed to shape, and flourish within, more sustainable sets of social and economic arrangements. I draw on some of the literature on the human capabilities approach (e.g. Nussbaum and Sen 1993; Nussbaum 2011; Gale and Molla 2015) to extend current accounts of desirable graduate attributes, and take this a little further by incorporating more recent writing on care and restoration - sketching what this might mean for an enrichment of our ambitions in university education (e.g. Flanagan 2019; Manne 2020; Puig de la Bellacasa 2017). The question then arises of how to proceed with further curriculum reform aligned with these more ambitious capabilities, and how to think about the infrastructure required (social, material, digital, hybrid).

I continue this part of the argument by discussing some shortcomings of "critical thinking' - a catch-all phrase that obscures as much as it reveals, and which continues to provide cover for what, following Kathleen Fitzpatrick, we might more accurately call 'ungenerous thinking'. Fitzpatrick (2019) shows how curriculum redesign, and reconsideration of pedagogy, can be informed by a greater valuing of, and closer attention to, collaboration and careful listening. I also draw on Hilary Cottam, Ezio Manzini and Sasha Costanza-Chock's analyses of the capabilities needed to engage in collaborative social innovation aimed at sustainable futures and just transitions (Manzini 2015; Cottam 2019; Costanza-Chock 2020). This leads inexorably to design. Not the commodified and sanitised expression of design thinking popularised by fans of IDEO (Brown 2009), but what Nelson and Stolterman (2014) refer to as the first human tradition: the union of inquiry and action that precedes both science and art. Anne-Marie Willis (2006: 70) puts it this way: 
... design is something far more pervasive and profound than is generally recognised by designers, cultural theorists, philosophers or lay persons ... designing is fundamental to being human - we design, that is to say, we deliberate, plan and scheme in ways which prefigure our actions and makings - in turn we are designed by our designing and by that which we have designed (i.e., through our interactions with the structural and material specificities of our environments) ... this adds up to a double movement - we design our world, while our world acts back on us ...

Following Nelson and Stolterman (2014), we can think of design as an integrating inquiry into what is true, what is real and what is ideal, disciplined by a commitment to making change in the world (Goodyear 2019). I suggest that this brings and holds together bundles of valuable practices that have the potential to provide stronger ground for university curricula than we find in the vocational, academic or critical traditions.

How might we better help students to develop the capabilities needed to work with others (inside and outside the university) on important, achievable improvements: through authentic engagement in just design and inclusive social innovation? How, for example, does one learn to build a provisional consensus on the scope of an intervention? How does one identify the bounds of a problem and of a concerned community? How does one set aside, from time to time, all the enervating critiques that flow from considerations of what one is not currently trying to resolve? I am not suggesting that such questions are appropriate for all students in all areas of curriculum. Rather, there are strong arguments for orienting some core curriculum experiences to gaining experience and confidence in handling such matters.

In the last main part of the paper, I pursue some implications for thinking about space and infrastructure. Costanza-Chock (2020) correctly observes that where design happens is consequential. Connell (2019) insists on the importance of face-to-face teaching, but I think this needs closer scrutiny. If we want to support more students spending more time engaging with communities beyond the university in various forms of collaborative inquiry and action (cf. Nørgård and Bengtsen 2016; Nørgård et al. 2019; Barnett 2018; Barnett and Jackson 2019), then we need to:

a) better understand how the campus provides social and epistemic infrastructure, as well as how it can exclude and disable,

b) go beyond calls to break down walls and render boundaries more permeable, and

c) identify, strengthen and extend infrastructures for design-led community engagement and the collective imagining of desirable futures.

While considering these matters, we need to acknowledge that students are always already engaged in the life of communities - local and networked - using a variety of tools and resources, depending on a range of existing infrastructures. Thinking more carefully about educational infrastructure may avoid wasting or distorting what already exists, and help build what is really needed. 


\section{Connell's Characteristics of the Good University}

In describing the five sets of characteristics of the good university, Connell (2019: 171-4) draws together some high-level values and ways of working, on which we can begin to build ideas about curriculum and infrastructure.

Democratic: the good university serves democratic purposes in society and operates in a democratic way.

The multiple, interlocking labour processes of research and higher education need constant coordination. Who can do that better than the people who know them best, who actually do the work? In a good university all the workforce are managers. (Connell 2019: 171)

This democratic way of working should also apply to the university's relations with society - strengthening democratic institutions and how they are understood and valued; harnessing and embodying a spirit of social justice to prioritise the needs of the least advantaged, not the reproduction of privileged elites.

Engaged: this means being 'fully present for the society that supports the university' (2019: 172). In turn, this entails: responding to social needs for knowledge - local and global; using local needs to inform research agendas; not dodging the big global questions; inviting students into 'strenuous learning projects' and questioning the foundations of professional practices.

Good teaching means being fully present for the students, engaging with their actual needs and enabling their next moves in learning. The pedagogy of engagement is demanding for teachers in time and emotion as well as technical knowledge. They must get to know specific groups of students, work with them, think about the resources and skills they need, and support them through a sustained learning process. Therefore a good university needs a secure teaching workforce and does most of its educational work face to face. (2019: 172-3)

Our shared sense of what 'face to face' means may well have shifted, after our experiences of emergency remote teaching. At a minimum, our thinking about the distributions of activity across space, time and media has become more complicated - with a concomitant awareness of the need to be able to design for more fluid arrangements of educational work.

Truthful: this involves understanding truthfulness as a property of the practices used in knowledge creation, rather than (solely) in terms of the truth value of a specific proposition. Teaching should emphasise how knowledge is produced and enable students to undertake their own inquiries.

It is a university's job to serve its society, not to agree with it. ... Intellectual labour involves a constant flow of questioning and critique. That is a crucial resource for societies facing difficulty and change, feeling their way into unknown futures. A good university, inevitably, is a bearer of oppositional ideas, an obstacle to privilege. (2019: 173) 
As will become clear later in the paper, I believe we need a more expansive sense than this of intellectual labour, one that captures more of the spirit and purpose of design and of the practical work involved in building things - places, institutions, courses, curricula etc. - that can survive in turbulent times and against the opposition of vested interests.

Creative: for researchers, this includes freeing up the research imagination and supporting researchers with freedom and resources. In teaching, this means 'foregrounding student agency in learning' (op. cit.: 174). 'Students do creative work when they study; it is they, not the teachers, who build the new intellectual structures in their own minds' (ibid.) — this needs infrastructure and support—permission for wildness and invention.

Sustainable: the university needs to be able to flourish over the long term, as do its people. This requires conscientious working within resource limits, but also sustainable long-term sources of income, healthy workplaces, limits on stress and secure conditions. It also involves sustaining the broader knowledge economy: "A good university freely circulates information, ideas and techniques, and acts steadily to build a knowledge commons in the world at large.' (ibid.).

\section{The Real Work of Realisation}

In some areas of academic writing about higher education, one can find authors with a problematic habit of positioning 'the university' as if it were a living, thinking, self-directing organism. Some authors frame their diagnoses and recommendations as exhortations directed at 'the university', as if it were a person who should mend their ways. One of the many strong points in Raewyn Connell's The Good University is her insistence on understanding each university as a real organisation, with a real workforce, doing real work, that has real effects. On this view, change occurs when people who work in universities change what they do, such that what they do has different effects. If we are interested in change now, or in the short to medium term, this means people in the current workforce have to change what they do. If course or curriculum designs, assessment or pedagogy are to change, real current members of the educational workforce have to think through the desired changes, discuss and agree what can be done and change rules and documents to crystallise and communicate new expectations. Moreover, for a designed curriculum to become an experienced curriculum, students have to complete the work their teachers have begun.

In this paper, in this special issue, we are particularly interested in spaces - and so I want to focus on discussions and planning on the boundaries between educational redesign and the design and management of the complex spaces in which students' activities unfold. The real work of realising convivial spaces for valued activities involves modes of thought, and lines of planning and discussion, that connect the macro and micro. This is the only way to forge real connections between (i) broad aims and statements about what we value (as in Connell's 'five characteristics') and (ii) the vital and consequential details of space and task design. Like good architects, anthropologists and ecologists, we have to move fluently between ways of 
knowing: weaving together constructs and insights from philosophy and ergonomics, sociology and psychology, to help connect minds, bodies and worlds.

Some university facilities are managed by staff who specialise in material spaces, such as classrooms, labs and lecture theatres. These staff are themselves managed by someone with a title like 'Director of Estates' or 'Director of Campus Infrastructure Services'. Some spaces are, at least in part, configured using digital tools that are managed by university staff who specialise in information technology. These staff are managed by a Chief Information Officer, or equivalent. I am interested in what happens in discussions between teaching staff (lecturers, instructors, 'faculty') and the staff who look after material and digital spaces. If the people in these roles the 'frontrunners, decision-makers and place-makers within the university' (Nørgård and Bengtsen 2016: 13) — lack the concepts and language needed to agree how to plan infrastructure to properly support educational activity, then misalignment is very likely (Boys 2015; Ellis and Goodyear 2019; Goodyear, Ellis and Marmot 2018; Kali et al. 2011; Könings et al. 2017). If the forms of educational activity are novel, it may be particularly difficult to align activity with spaces. In consequence, if educational change depends for its success, at least in part, on the spaces that support it, then lack of shared concepts and language will provide a fatal block on educational aspirations, no matter how progressive they may be.

In this paper, I am particularly interested in pursuing a set of connections between opportunities for students to participate in design-led social innovation activities and the kinds of infrastructure needed to support such activities. Irrespective of this specific interest, the broader argument still applies: staff in universities (as well as their students) can benefit from better ways of discussing and reflecting on what they are trying to do. As Krippendorff puts it:

No profession, no academic discipline can survive without providing its members the ability to explain themselves to others, continuously improve their proficiency, and demonstrate the benefits they can bring to collaborations with others. Explanations of this kind are constituent parts of a discourse. ... They are manifest in the kind of arguments designers [and other professionals] use to justify their decisions to those who matter. (Krippendorff 2006: 267-8)

This involves identifying areas of language and ideas that may be particularly helpful, and steering away from areas of language and sets of ideas that can prove problematic. It also turns out to be useful to have shared, sharp ways of dividing up the problem space of educational design - to think and talk about different areas of design and different kinds of design objects, such as tasks, activities, roles, divisions of labour, tools and spaces (Goodyear et al. 2021). Equally important are the 'connecting constructs' that allow discussion to develop and pursue logical inferences (design propositions) about how designable objects, educational activities and desirable outcomes relate to one another. Such constructs are required to answer questions like - what resources will the students need, in order to succeed with this task? In what follows, I suggest two terms of art that are well-established in various areas of literature, but which are still struggling to find a secure place in educational design discussions. These are 'practice' (especially when understood in terms of 'valued social practices' and 'affordance' (as a construct for reasoning 
about connections between a person and their activity and important features of their environment).

\section{Valued Practices and Their Infrastructures}

The lingua franca of Anglophone higher education is suffused with ideas about teaching as transmission. A central place is given to the lecture. A teacher's command of a subject and the clarity of their exposition are highly prized. Knowledge is a thing to be 'got across' by teachers and 'acquired' by students. Curricula are built on assumptions about pre-requisites and progression.

This is not to say that other ideas about teaching and learning are absent, far from it, but the availability of the discourse of 'teaching as telling' — the way that apparently shared terms come readily to hand (mouth and mind) in meetings of teams and committees, and in policy documents - has a shaping effect on the kinds of arguments and decisions that are advanced, heard and dismissed. Conversely, and especially in discussions involving teaching staff and the staff who manage physical and digital infrastructures, educational language that evokes more esoteric ideas about learning and teaching can be viewed with distrust.

When I hear the word 'pedagogy', I reach for my gun. (IT director, UK university; quoted in Ellis and Goodyear 2019: 185)

Partly as a response to this lack of shared language and trusted concepts for the discussion of the infrastructural needs of unfamiliar educational arrangements, Ellis and Goodyear (2019) proposed using a set of ecological constructs and a set of systemic methods for collaboratively analysing future learning needs. Such constructs foreground relations between person and environment. Ellis and Goodyear (2019) apply theoretical accounts of situated learning and activity systems to outline a range of approaches to the design, planning, management and use of novel learning environments.

As with many such discussions of person-environment relations, Ellis and Goodyear (2019) draw on James Gibson's ecological psychology for the notion of 'affordance' (Gibson 1977). I want to revisit that idea using more recent theorising by Erik Rietveld and colleagues (Rietveld and Kiverstein 2014; van Dijk and Rietveld 2017; Rietveld et al. 2018). Rietveld's work is useful, for the purposes of thinking about spaces for higher learning, in that it enriches the concept of affordance by connecting it to sociomaterial practices. Before explaining his ideas, I also want to claim that the notion of valued practice is itself a potentially useful addition to the lexicon of university teaching and infrastructure planning.

\section{Sociomaterial Practices}

Looking at it close-up, the activities in which people engage can seem infinitely varied. Observed over time, or from a distance, patterns begin to emerge. We can label some of these persisting patterns of activity 'practices'. There are many 
definitions of 'practice' in the substantial literatures on social practices and practice theory. This one from Kemmis and colleagues captures key points, bringing together 'doings, sayings and relatings'.

A practice is a form of socially established cooperative human activity in which characteristic arrangements of actions and activities (doings) are comprehensible in terms of arrangements of relevant ideas in characteristic discourses (sayings), and when the people and objects involved are distributed in characteristic arrangements of relationships (relatings), and when this complex of sayings, doings and relatings 'hangs together' in a distinctive project. (Kemmis et al. 2014: 31)

Some practices are quite specialised - perhaps unique, or at least distinctive, to a professional group. Thus, we can speak of the characteristic professional practices of school teachers, surgeons and builders, for example (Kemmis 2019). Distinctive knowledge-creating (or 'epistemic') practices characterise different academic disciplines (Knorr-Cetina 1999; Markauskaite and Goodyear 2017). So one way to think about university education is as an induction into, or an apprenticeship in, an area of professional or academic practice. On this view, educational design can be oriented to giving students opportunities to experience being legitimate peripheral participants in professional and/or academic practices and communities (Lave and Wenger 1991). Their participation needs to be scaffolded in various ways, though the quantity of scaffolding may be decreased over time, as the students move centripetally to become less peripheral (more central, more able, more visible) participants in the practices and communities concerned.

Attaching the word 'social' to 'practices' may seem redundant, insofar as it is hard to imagine practices that are not social. By the same token, one may object to the term 'sociomaterial practices', since surely all practices involve other people and also things (tools, devices, workplaces, and so on). But the prefix is easy to justify in circumstances where we want to be sure that the involvement of other people and material things stays visible and is seen as consequential. Moreover the fused word 'sociomaterial' underscores the ways in which the social and material are entangled and constitute one another.

Social thought has had an unsteady relationship to the material world. ... although some recent social theory has attended to materiality, it still regularly underestimates the contributions made to social affairs by material entities, the material properties of things, and the processes that happen to these entities by virtue of these properties... (Schatzki 2019: 51)

It turns out that many university teachers, innovative and otherwise, draw explicitly and implicitly on the idea of professional and/or academic practices in both curriculum and learning space design, though they may not use the language of practice theory to do so. Rather, designing learning tasks and learning spaces can be easier, and can happen more naturally, so to speak, if what is set in place for students is a simplified version of some valued professional or academic practice (Goodyear 2020). 
My suggestion, here, is twofold. First, if many teachers are already spontaneously engaging with course, curriculum and learning space design by thinking about how to engage students in simplified and scaffolded version of valued practices, then we can build on that base by analysing, describing and disseminating important aspects of what they are doing. (This is not widely acknowledged in the educational design literature yet.) Second, for reasons to be elaborated below, we should add to the collection of valued sociomaterial practices in which students get opportunities to engage, some practices associated with social innovation, the search for just transitions, care, community-building and the development of other generative human capabilities.

\section{Postdigital Infrastructure}

The digital is no longer new: it has spread across vast spaces in the world, like a rhizome or a network of fungi whose mass, connections and interdependencies are largely hidden from view (Macgilchrist 2021). The term 'postdigital' is useful insofar as it prompts us to recognise this virtual ubiquity while remaining alert to the fact that 'the digital' is still interesting - worthy of further scrutiny (Sinclair and Hayes 2019). 'Postdigital' also pushes us to question and avoid the sharp binaries - 'digital vs real', 'online vs face-to-face', 'artificial vs natural worlds', and 'human vs technological' - and to look for and work with amalgams and hybrids (Fawns 2019; Nørgård et al. 2019; Macgilchrist 2021).

The infrastructure in education has both a technical and a social character and the activity of individual academic innovators is conditioned by the kinds of infrastructures for learning that are provided for them. (Jones 2015: 6)

The same is true of the activities of students and also of broader partnerships engaged in collectively imagining desirable changes (Oldham 2021).

Definitions of infrastructure tend towards the relational, such that some would argue that the defining question is not what is infrastructure, but when is infrastructure: in the sense that infrastructure is drawn together for particular purposes and activities. Looking more closely, one might say that some of the material, social and (of course) sociomaterial arrangements we find in the world pre-exist a specific, concrete, activity and provide resources for it. In so doing, infrastructure provides a landscape of affordances (see below). Within universities, infrastructures develop over time - indeed some people are given professional responsibility for overseeing their maintenance and enhancement — and infrastructures are also subject to diurnal and hourly changes, as when classroom furniture is rearranged, or laboratory workbenches are restocked with materials. Crucially, infrastructure needs to be considered from at least two perspectives, or within dual ontologies: as (i) a set of objects to be designed, planned and managed and (ii) as entangled and experienced in real activities (Goodyear et al. 2021). So in thinking about postdigital infrastructure, we need to be sure to include: the social, digital, material and hybrids; the planned and the experienced. 


\section{Affordance}

The term 'affordance' is widely used, and its utility widely debated, in the literatures of human computer interaction (HCI) and educational technology (see e.g. Norman 1999; Turner 2005; Laurillard 1987; Oliver 2005; Dohn 2009; Goodyear and Carvalho 2019; Davis 2020). It originates in the work of the ecological psychologist James Gibson (1977). For Gibson, affordances are possibilities for action provided to an animal (human or otherwise) by the environment-by the 'substances, surfaces, objects, and other living creatures that surround it' (Rietveld and Kiverstein 2014: 325). An affordance offers, invites, solicits, furnishes or provides. It can be thought of as both an objective element of an environment and a subjective perception by an animal. It may be better to think of it as both, or as relational. Moreover, affordances can be found in artificial environments - for example, as objects on a computer desktop that are designed to suggest some action (like clicking or dragging) or, in classrooms, such as when chairs and tables are laid out in clusters for group work, rather than in straight lines for a lecture. Goodyear and Carvalho (2019) argue that designed learning environments have effects on how students use them that operate through a mixture of (directly and quickly perceived) affordances and (slower, more cognitively demanding) interpretive processes. Thinking about this mixture of processes can be used in order to reason about connections between aspects of a learning environment (or tool, or resource) and student activity. Such reasoning can avoid technological determinism, in that affordances are offers that do not have to be taken up, but can nevertheless inform principled design choices, in that the architecture and 'furnishings' of a designed environment for learning should not be random or arbitrary. 'Affordance' is therefore a useful 'connecting construct' of the sort I mentioned earlier.

Much of the discussion of the utility and coherence of the concept of affordances in the educational technology and learning spaces literature has been hampered by a tendency to think and write in terms of simple, static objects with fixed 1-to-1 mappings to action choices. (As when an icon on a computer screen is said to afford clicking.) Rietveld and colleagues show that this kind of simplified conceptual treatment undermines a proper understanding of how affordances function. Rietveld's account centres upon a Skilled Intentionality Framework (SIF) which elaborates the theoretical treatment of affordances in five very helpful ways (van Dijk and Rietveld 2017; Rietveld and Kiverstein 2014).

Firstly, affordances are to be understood as always already situated - in the sociomaterial practices that make up a particular form of human life. Secondly, in human forms of life, the social and material are entwined; hence, one should speak of the sociomaterial. Thirdly, affordances are multiple and nested: best conceived in terms of 'landscapes of affordances'. Fourthly, people's situated action is characterised by skilled intentionality: 'coordinating with multiple affordances simultaneously in a concrete situation' (van Dijk and Rietveld 2017: 8) and that this involves 'bodily states of action readiness' (loc. cit.) developed through experience. Finally, sociomaterial environments are often in flux — SIF helps explain how situations are extended in the transition between one activity, or practice, and another. (Consider, 
for example, the actions and reshaping of affordances typical in the last few minutes of a university lecture.)

van Dijk and Rietveld (2017) also argue that SIF, affordances and sociomaterial practices need to be understood from three perspectives: a 'zoomed out' view, in which stable patterns of behaving are observable, such that we can discern discrete practices or forms of life; a 'zoomed in' view, of the kind we associate with an ethnographer doing close-up research; and a 'first person' view that captures the actor's lived experience. While the close-up view no longer reveals the stable patterns and regularities (recurrent practices), it does show us real-time change - reconfigurations of the environment, changes in the landscape of affordances and the kinds of action solicited, and people's coordination with others. To that, the 'first person' perspective adds a sense of how the indeterminacy of relations between environment and actor as they appear to the observer have greater consistency and predictability 'on the inside'.

This richer triple perspective on affordances, I suggest, provides better intellectual resources for analysing, planning and discussing relations between university spaces, and other infrastructure, on the one hand, and valued activities for students, on the other.

\section{Valued Practices, Human Capabilities, Care and Restoration}

Over the last few decades, many staff in universities have thought expansively about the connections between higher education and work, moving the debate, and the direction of educational innovations, from narrow government and business directives about 'job ready graduates' to consider much wider notions of employability (Higgs et al. 2019). Some of these initiatives have coalesced with commitments to education for citizenship (Heggart 2020). In consequence, it is possible to find a wide range of high-level statements about general graduate attributes and/or about what university education should provide.

Within this heterogeneous body of writing and educational action, I want to focus in upon some strands of thinking that have roots in the human capabilities approach advanced by Martha Nussbaum and Amartya Sen (Nussbaum and Sen 1993; Nussbaum 2011). The human capabilities approach can be understood as a reaction against narrow economic measures of well-being: a redefinition of worthwhile goals for policy and development that focuses on specific kinds of substantive freedom. This focus on freedoms involves a shift of view, from people as passive loci of intersecting needs, awaiting fulfilment by others, to people as reasoning agents of collaborative change.

... we also have to go beyond the role of human beings specifically as 'consumers' or as 'people with needs', and consider, more broadly, their general role as agents of change who can-given the opportunity-think, assess, evaluate, resolve, inspire, agitate, and, through these means, reshape the world. (Sen 2013: 7) 
On this view, what matters is a person's capability to make a life they have reason to value, rather than the resources they possess or their self-reports of need satisfaction. What is it they are able to do, and to be? It is important to note that capabilities do not simply reside in a person - they are the:

freedoms or opportunities created by a combination of personal abilities and the political, social, and economic environment. (Nussbaum 2011: 20)

In other words, these too are relational. As we start to trace some of the implications of this for course and curriculum design, it is important to think about intended outcomes on two levels - what will benefit the students themselves, directly, and what will help them, in the future, to work in ways that benefit others. The potential synergies between these two are also important, not least in applying ethics and strategies for mutual care to students' relations with their peers.

Frances Flanagan helps us think more clearly about some of these relationships between sustainability, just transitions, employment, the constitution of jobs and capabilities - and how we might consider more carefully the links between preparation for work, the way work is organised and valued, and issues of sustainability and restoration.

In Flanagan's view, the dominant narratives about the future of work and of life on the planet underestimate and/or undermine human agency and implicitly dismiss work and the workplace as 'a viable stage upon which we might collectively struggle for a better system' (Flanagan 2019: 4).

And just as it is premature to give up on the possibility of a new social order, so too is it hasty to abandon the idea that work can be a political site from which to fight for the reform. For there is a crucial link between 'sustainability' and work that is perhaps very obvious but rarely made explicit: the process of 'sustaining' requires human labour. It means more than simply saying 'no' to damaging acts of consumption; it also means saying 'yes' to the human activities that are positively necessary for the repair, renewal and regeneration of our soils, our oceans, our cities, our critical human systems and our human bodies. A society that exists within planetary limits is one that looks on such work as more than just an afterthought or 'non-core' aspect to the 'real' business of production. It rather treats it as utterly elemental. (Flanagan 2019: 4)

Flanagan provides a number of compelling examples of people whose work involves providing care - to other people, to the land, and to other animals — but where the circumstances in which they work do not allow them to flourish.

Their work is environmental. Not in the narrow sense of being low-carbon-emitting (although it is that). Nor in the sense that it boosts biodiversity (although some do that too). Their work is environmental because it is centrally concerned with human and non-human regeneration, and in particular with fostering social cohesion, trust, civility and a sense of order. It is environmental because it fosters education and the passing on of learning about how to live wisely and within limits. No society can simultaneously exist within environmental limits and be a democracy that does not possess an abundance of these things. ... Many, if not most, of these workers live 
under the shadow of a glaring mismatch between the status of their work (in terms of pay and security) and the social value it creates. For we reward and support the stewards of renewal far less generously than we do the stewards of extraction and consumption. (op. cit.: 6)

In the next section, I look more closely at forms of care enacted in and through collaborative design and social innovation.

\section{From Critical to Generous Thinking, and Onwards to Social Innovation and Design}

In a recent book on rethinking university education, Kathleen Fitzpatrick makes a strong case against a very recognisable, highly contagious variant of 'critical thinking'. (Writing before Covid-19, she calls it a 'metastasised' version.) It is not so much that the critical mode is inappropriate, but that its hegemony in intellectual life privileges negation over creation and manifests as a refusal to listen. When critique is weaponised to create individual distinction - to get ahead in competitions with, and to 'outradicalise', one's peers - it becomes corrosive. In turn, this makes it very hard for critically primed academics and their students to engage with wider publics and the aspirations and projects that matter to them. In contrast, Fitzpatrick describes 'generous thinking' as a mode of engagement that emphasises.

listening over speaking, community over individualism, collaboration over competition, and lingering with the ideas that are in front of us rather than continually pressing forward to where we [individually] want to go. (Fitzpatrick 2019: 4).

The point is not, of course, to blunt judgements or to say that 'anything goes'. Rather, a disposition towards generous thinking — and I would say, the encouragement of practices of generous thinking — shifts the centre of effort towards care and community building. This is not a romantic notion: not an idealisation of community. Rather, it uses ideas about community actively and self-consciously, as a way of building consensus and solidarity around lines of action that people have reason to pursue. On this view,

... the best of what the university has to offer lies less in its specific power to advance knowledge or solve problems in any of its fields than in its more general, more crucial ability to be a model and support for generous thinking as a way of being in and with the world. (Fitzpatrick 2019: 5-6)

This aligns thinking, action and care. It values community-building for a purpose: to pursue certain kinds of projects or lines of action. It also values community-building for its own sake, and says that communities thrive on joint activity. It raises serious questions about conventional views of efficient action and suggests. 
.. a hard turn away from efficiency as a primary value, and thus a recognition that the building of relationships and the cultivation of care are slow and difficult and of necessity inefficient (Fitzpatrick 2019: 10).

This is also a turn away from competitiveness and the critical reflex, to embrace what might be termed the 'postcritical'. By this I mean a set of approaches to understanding and helping change the world that (a) retain a critical sensibility while (b) avoiding the condescension implicit in the roles of critical master and naive student and (c) locating action in the world we have now, rather than postponing it into some rosy revolutionary future.

Instead of hierarchical relations between a master of critique and an ignorant student, education is conceived as an act of giving, which creates common ground between the generations. Rather than ceaselessly calling for a brave new world in an imaginary, unattainable future, post-critical education calls for renewing the existing world based on what is good and worthy in it. Prevailing injustice is not denied, and education by no means excludes politics: it simply refuses to force predetermined 'critical' patterns on reality, allowing the new generation to be political in its own way, to question the politics of the older one. (Snir 2021: 202-3)

The importance of paying attention, simultaneously, to both human relationships and lines of practical action is central to the design-led social innovation practice of Hilary Cottam and colleagues (e.g. Burns et al. 2006; Cottam 2019). Cottam's work is strongly influenced by the capabilities approach of Nussbaum and Sen, as can be seen in the following summary of her methodology, which she contrasts with existing welfare systems that manage dependence:

This new way of working and being starts in a different place. The question is not how can we fix these services, but rather, as I stand beside you, how can I support you to create change ... the emphasis is not on managing need but on creating capability. ... At the heart of this new way of working is human connection ... when people feel supported by strong human relationships, change happens. And when we design new systems that make this sort of collaboration and connection feel simple and easy, people want to join in. This is not surprising, and yet our current welfare state does not try to connect us to one another, despite the abundant potential of our relationships. (Cottam 2019: 15, emphasis added)

Cottam summarises the insights gained through her experiments with social innovation, over the years, by highlighting the importance of four kinds of capabilities:

1. Learning: the ability to grow through inquiry, meaningful work and the development of imagination.

2. Health: mental and physical vitality are central to a flourishing life.

3. Community: being part of, and contributing to, local and global communities in search of sustainable ways of life.

4. Relationships: supportive and close bonds with other people. 
And of these she finds that relationships matter more than anything else.

Relationships - the simple human bonds between us - are the foundation of good lives. They bring us joy, happiness and a sense of possibility. And they are what Martha Nussbaum calls 'architectonic'. Building on relationships enables the growth of further capability: supporting us to learn, contributing to good health and vibrant communities. Without strong bonds with others, or with unhealthy relationships, very few of us can feel fulfilled - or even function (Cottam 2019: 205)

We can also think about our students gaining capabilities that enable them to participate creatively in what the design theorist Ezio Manzini calls 'the great transition' - the complex mix of processes through which humanity is coming to terms with planetary limits while simultaneously appreciating and making better use of human-human connections. Practices of social innovation are at the heart of this - the practices through which new ideas, products, services, models, frameworks and so on are created, and which meet social needs and create new social relationships. Manzini draws on Nussbaum and Sen to reposition design, and design experts, in a world in which 'everyone designs'. In previous work, I have argued that this framing can be extended to think more broadly about university curricula for professional preparation. Now, I would suggest that it is relevant for induction into many of the valued practices of disciplines and professions in which action and inquiry (sense-making) come together (Goodyear 2019).

In this way of seeing things, the role of design experts is no longer that of developing finished products and services. Instead, their task is to design to expand the capabilities of people to lead the kinds of lives they value. This means that, rather than trying to identify needs and design solutions to satisfy them, design experts should collaborate in creating favorable conditions for those directly concerned to come up with and put into practice ways of living and acting to which they themselves, the protagonists, attribute value.... while design experts, while intervening in the design of the enabling solution, do not determine the way in which people will decide to operate, they do create action platforms and sense systems thanks to which different behaviour may be more or less viable and more or less culturally commendable, and therefore more or less probable. (Manzini 2015: 98, emphasis added)

In fine-tuning this conception of the kinds of participation in practices of social innovation that we might be aspiring to help our students prepare for, we ought also to take properly into account the imperatives of socially just transitions to sustainable forms of living. Figure 1 uses Kate Raworth's celebrated model from 'doughnut economics' to underscore this point (Raworth 2017). Navigating a set of paths towards a regenerative and distributive economy and a safe and just space for humanity (Fig. 1) entails social innovation practices aimed at avoiding both ecological overshoots and socioeconomic shortfalls.

Some social innovation practices are more oriented to the outer bound of the doughnut: designing, testing and refining products, services and ways of living so 


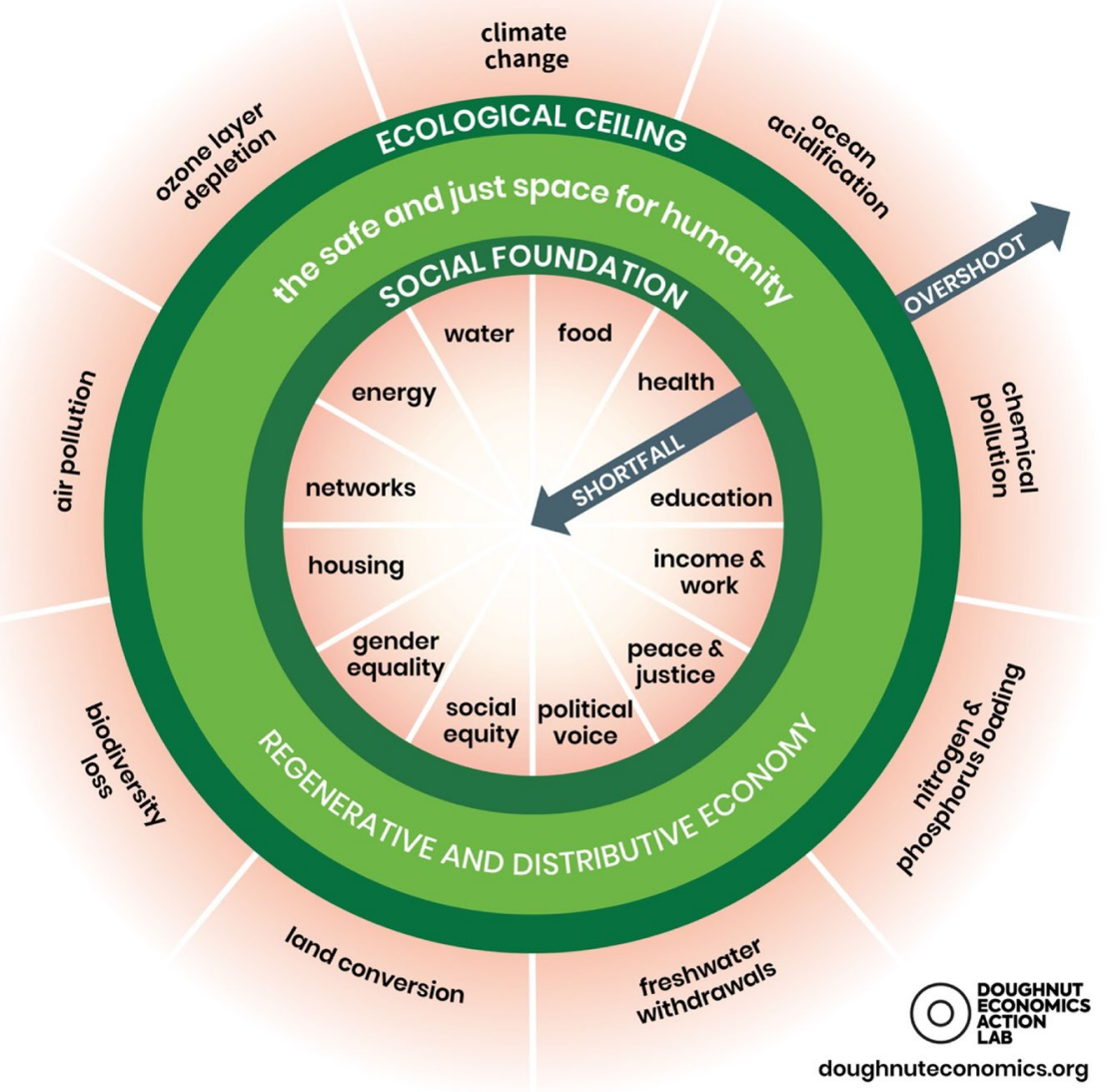

Fig. 1 The doughnut of social and planetary boundaries (Kate Raworth and Christian Guthier. CC-BYSA 4.0)

as to ensure that we live within planetary limits, not overshooting the ecological ceiling. Other social innovation practices are more oriented to the inner bound of the doughnut: where the goal is to ensure that everyone's basic needs are met, avoiding shortfalls that lead to deprivation for any social groups. Making paths to the just and sustainable middle-ground involves more than talk and critique: it necessitates widespread engagement in design and creation, imbued with what Sasha Constanza-Chock and colleagues call 'design justice'.

Design justice is a framework for analysis of how design distributes benefits and burdens between various groups of people. ... Design justice is also a growing community of practice that aims to ensure a more equitable distribution of design's benefits and burdens; meaningful participation in design decisions; and recognition of community-based, Indigenous, and diasporic design traditions, knowledge, and practices. (Constanza-Chock 2020: 23). 


\section{Spaces for Learning to and Through Design}

What does this all mean for thinking about postdigital spaces in higher education? I would like to draw out two lines of argument here. The first briefly explores what more might be said about planning the infrastructure for sets of higher education practices that induct students into legitimate and decreasingly peripheral participation in social innovation and participatory design. The second proposes that such ways of thinking about practices and infrastructure are potentially of wider value: they may be useful for planning spaces for other kinds of practices.

\section{Spaces for Participation in Social Innovation and Participatory Design}

A university campus is not just a composition for containing academic life, making sure that people do not get wet during lectures or have office space to work in. It is a site engraved with certain ethical and ideological implications; it emanates certain values, calls for certain forms of participation and speaks to us in a certain 'voice' ... As such, the university is a certain offer of experience ... (Nørgård and Bengtsen 2016: 7).

Sasha Costanza-Chock (2020) reminds us that considerations of design justice must include asking questions about the placing of design. Where does design happen? What sites of design are privileged and why? How do we make design sites accessible to the people who will be most impacted by, and/or who have most to offer to, processes of design? What existing design sites are marginalised and ignored?

I suggest that we can approach this by thinking from two directions. Firstly, we should consider plans for material places set up on campus and configured to support students who are learning to participate in practices of design for social innovation: developing mastery of, and confidence in, relevant ideas, tools and methods, in a low-risk way. To make things concrete, we could think in terms of design studios, with appropriate versions of the sociomaterial infrastructures and practices associated with collaborative design of new services. Secondly, we should find and recognise sites outwith the campus in which social innovation (broadly understood) is already underway. Wherever there is a problem, there will already be people working on solutions, and it is important to recognise and value what they already know (Costanza Chock 2020; Calvo and Sclater 2021).

With these two imagined poles in place, we can begin to think and work carefully, respectfully and tactfully towards ways of bridging between sites, through the creation of tools and infrastructures, relationships, jointly understood aspirations and shared projects. This involves encouraging movement in both directions: making the campus boundaries more permeable, making it easier for people who are not used to universities to feel comfortable in university spaces and supporting students who may feel underprepared or nervous about forging new community links. (In all of this, we must also remember that most students are already involved in various kinds of communities and networks, local and more global.) Technical and 
pedagogical innovations may be needed to help with this bridging work. University CIOs and their staff are understandably careful about security, but being overzealous about security quickly shades into digital exclusion and renders collaboration with local communities unnecessarily difficult. Nor is it obvious that social media platforms offer an easy solution here. Each comes with costs and risks.

Within all of this work on infrastructure and novel hybrid spaces to strengthen university-community links, it is also vitally important to think about the need for students to get better at self-care and care for their peers, not least at forming better relationships with students from diverse backgrounds: a notoriously weak area in Australian universities (Ellis and Goodyear 2019: 26-7).

We must design ways to encounter and get to know those who are not like us if we are to flourish. And we can do this in ways that are simple, intuitive and authentic. ... Relationships sit at the heart of the good life, and our capacity to relate to one another is infinite. (Cottam 2019: 207)

Thinking back to Fitzpatrick's emphasis on careful listening, I would suggest that our considerations of infrastructure need to pay much more sophisticated attention to affordances which amplify and record quiet and unfamiliar voices: the stories of those who are pushed to the margins and sometimes silenced by arrangements that privilege the quick, loud and competitive. This applies to discussions among students, and to discussions with members of other communities. Poor acoustics and poorly chosen spaces make it close to impossible for anyone to voice complex or risky ideas.

Conversely, well-chosen tools and well-managed spaces can help us all hear the articulation of diverse needs, skills and aspirations and retain what is said for future reference. (The academic practice of wiping course discussion boards clean at the end of each year makes clear how poorly we value students' contributions.)

\section{How to Think About Practice-Space/Infrastructure Links More Generally}

A good university does not build palaces for itself. It lives at the level of its society as a whole. ... A good university will have a modest demeanour in the world. When it needs to teach in a shack, it will teach in a shack. (Connell 2019: 174-175)

Thinking more generally about what spaces are needed — whether a shack, a townhall or a studio - I suggest that this is not primarily a matter of pedagogy. Pedagogical theory and theories of learning can be very useful in designing good tasks, from which productive learning activities may flow. Ethnographic observation (zoomed out and zoomed in), coupled with first-person insights from interviews, can reveal a lot about valued sociomaterial practices and the skills involved in navigating a landscape of affordances. Knowing how to find and reconfigure spaces, or make places, that afford joint inquiry and collective action should not be the preserve of academics and those who manage infrastructure. It should be an aim of education to make this common knowledge. 


\section{Concluding Comments: Navigation, Design and Locking in Achievements}

There is no doubt that these are testing times for universities. It is both understandable, and right, that deep questions are being asked about relations between the ways that universities work and are constituted, the ongoing injustices of colonialism, racism, sexism and ableism, the marginalisation of under-represented groups and the reproduction of economic, social and cultural privilege (Connell 2019; Snaza and Singh 2021). For some commentators, the university is always in crisis. What effect does this commentary have on what transpires within our institutions? What can be done, beyond naming sources of oppression and distortion, and organising forms of resistance? Kathleen Fitzpatrick suggests that the critical stance has not got us very far.

... not only is capital extraordinarily able to absorb all critique and to marginalize those who make it, but our inability to stop competing with one another ensures that our critique is contained within the forces of the market we serve. (Fitzpatrick 2019: 30)

Those of us who are ill-at-ease with current arrangements often seem to have a shared, if vague, sense of where we want to get to, but we never seem to be in the right place to start the journey. Incremental change 'from within' is, of course, subject to many forms of subversion and obstruction, especially by those with a vested interest in maintaining the status quo. And yet, we are where we are, and we need to make roads and build bridges in order to move at all. Creating new spaces for learning requires us to work (reflexively) on what Arjun Appadurai calls 'navigational capacity' (Appadurai 2004). Navigational capacity is what allows people to aspire, to look up, to look at the future and map plausible routes towards states of affairs that they have reason to value.

The capacity to aspire is thus a navigational capacity. The more privileged in any society simply have used the map of its norms to explore the future more frequently and more realistically, and to share this knowledge with one another more routinely than their poorer and weaker neighbors. The poorer members, precisely because of their lack of opportunities to practice the use of this navigational capacity (in turn because their situations permit fewer experiments and less easy archiving of alternative futures), have a more brittle horizon of aspirations. ... I am not saying that the poor cannot wish, want, need, plan, or aspire. But part of poverty is a diminishing of the circumstances in which these practices occur. (Appadurai 2004: 69)

Navigational capacity includes the means to link broad social concerns and values to details of action in the here and now, to locally plausible steps that can be taken in the immediate future, and to the nurturing of complex webs of relationships with people and agencies in positions of power. Such ways of acting link the macro to the micro, and back again, in a fashion that is rarely modelled - at least in the open by university leaders or by those who write generally about universities and higher 
education policy. However, this commitment to spotting and getting the devil out of the details, and to testing constraints by tinkering with candidate solutions, is core to the professional skills of architects and many designers. Indeed, Appadurai draws frequently on design, to speak of the ways in which cultures use norms, beliefs and values to design forms of social life, the ways in which ordinary people operate through cultural designs to anticipate the future and manage risk, and how activists and bureaucrats find themselves exploring new designs for partnerships. Appadurai's illustrations are drawn from the long-term strategies of a well-established and successful Alliance that works among and for the poorest people of Mumbai. But it seems to me that some of the ground rules and working practices they have developed are worth considering in relation to the realisation of The Good University. We could do worse than translate this into the terms of our own struggle:

From this perspective, the politics of the Alliance is a politics of accommodation, negotiation, and long-term pressure rather than of confrontation or threats of political reprisal. This pragmatic approach is grounded in a complex political vision about means, ends, and styles which is not entirely utilitarian or functional. It is based on a series of ideas about the transformation of the conditions of poverty by the poor in the long run. In this sense, the idea of a political horizon implies an idea of patience and of cumulative victories and long-term asset building which is wired into every aspect of the activities of the Alliance. The Alliance believes that the mobilization of the knowledge of the poor into methods driven by the poor and for the poor is a slow and risk-laden process that informs the strong bias of the Alliance against 'projects' and 'projectization' that underlies almost all official ideas about urban change. (Appadurai 2004: 73, emphasis added)

Realising The Good University also depends upon alliances - in which students and their teachers, and local and extended communities develop a shared sense of valued futures and how progress can be made towards them. I do not recall a time when work towards a good university was consciously organised as a long-term, multi-decadal task, to be pursued patiently and with alert determination by an alliance capable of locking in successive achievements and cumulative victories. On the other hand, there's no time like the present.

Acknowledgements Figure 1 'The Doughnut of social and planetary boundaries' by Kate Raworth and Christian Guthier is reproduced under Creative Commons licence CC-BY-SA 4.0. Copies can be downloaded from: https://doughnuteconomics.org/tools-and-stories/65. See Raworth (2017) for further information.

Funding This work was part-funded by the Australian Research Council through grants DP150104163 (Modelling complex learning spaces) and DP200100376 (Developing interdisciplinary expertise in universities). 


\section{References}

Appadurai, A. (2004). The capacity to aspire: culture and the terms of recognition. In M. Walton \& V. Rao (Eds.), Culture and Public Action: A Cross-Disciplinary Dialogue on Development Policy. World Bank Publications.

Barnett, R. (2018). The ecological university: a feasible utopia. Abingdon: Routledge. https://doi.org/10. $4324 / 9781315194899$.

Barnett, R., \& Jackson, N. (Eds.). (2019). Ecologies for learning and practice: emerging ideas, sightings and possibilities. Abingdon: Routledge.

Boys, J. (2015). Building better universities: strategies, spaces, technologies. Abingdon: Routledge.

Brown, T. (2009). Change by design: how design thinking transforms organizations and inspires innovation. New York: HarperBusiness.

Burns, C., Cottam, H., Vanstone, C., \& Winhall, J. (2006). Transformation design. London: Design Council.

Calvo, M., \& Sclater, M. (2021). Creating spaces for collaboration in community co-design. International Journal of Art \& Design Education, 40(1), 232-250. https://doi.org/10.1111/jade.12349.

Connell, R. (2019). The good university: what universities actually do and why it's time for radical change. Clayton, Victoria: Monash University Publishing.

Costanza-Chock, S. (2020). Design justice: community-led practices to build the worlds we need. Cambridge MA: MIT Press.

Cottam, H. (2019). Radical Help: How we can remake the relationships between us and revolutionise the welfare state. London: Little Brown.

Davis, J. L. (2020). How artifacts afford: the power and politics of everyday things. Cambridge, MA: MIT Press.

Dewey, J. (1958). Art as experience. New York: Capricorn Books.

Dohn, N.(2009). Affordances revisited: articulating a Merleau-Pontian view. InternationalJournalofComputerSupported Collaborative Learning, 4(2), 151-170. https://doi.org/10.1007/s11412-009-9062-z.

Ellis, R., \& Goodyear, P. (2019). The education ecology of universities: integrating learning, strategy and the academy. Abingdon: Routledge.

Fawns, T. (2019). Postdigital education in design and practice. Postdigital Science and Education, 1(1), 132145. https://doi.org/10.1007/s42438-018-0021-8.

Fitzpatrick, K. (2019). Generous thinking: a radical approach to saving the university. Baltimore: Johns Hopkins University Press.

Flanagan,F.(2019).Climate change and the new workorder. InsideStory, 28February.https://insidestory.org.au/ climate-change-and-the-new-work-order/. Accessed 28 July 2021.

Gale, T., \& Molla, T. (2015). Social justice intents in policy: An analysis of capability for and through education. Journal of Education Policy, 30(6), 810-830. https://doi.org/10.1080/02680939.2014. 987828.

Gibson, J. (1977). The theory of affordances. In R. Shaw \& J. Bransford (Eds.), Perceiving, acting, and knowing: Toward an ecological psychology (pp. 67-82). Hillsdale, NJ: Lawrence Erlbaum Associates.

Goodyear, P. (2019). Networked professional learning, design research and social innovation. In A. Littlejohn, J. Jaldemark, E. Vrieling, \& F. Nijland (Eds.), Networked professional learning: emerging and equitable discourses for professional development (pp. 239-256). Cham: Springer. https://doi.org/10.1007/978-3030-18030-0_14.

Goodyear, P. (2020). Design and co-configuration for hybrid learning: Theorising the practices of learning space design British Journal of Educational Technology, 51(4), 1045-1060. https://doi.org/10. 1111/bjet.12925.

Goodyear, P., \& Carvalho, L. (2019). The analysis of complex learning environments. In H. Beetham \& R. Sharpe (Eds.), Rethinking pedagogy for a digital age: principles and practices of design (3rd ed., pp. 49-65). Abingdon: RoutledgeFalmer.

Goodyear, P., Carvalho, L., \& Yeoman, P. (2021). Activity-Centred Analysis and Design (ACAD): core purposes, distinctive qualities and current developments. Educational Technology Research and Development, 69(2), 445-464. https://doi.org/10.1007/s11423-020-09926-7.

Goodyear, P., Ellis, R., \& Marmot, A. (2018). Learning spaces research: framing actionable knowledge. In R. Ellis \& P. Goodyear (Eds.), Spaces of teaching and learning: integrating perspectives on 
research and practice (pp. 221-238). Singapore: Springer Nature. https://doi.org/10.1007/978-98110-7155-3_12.

Heggart, K. (2020). Activist citizenship education: a framework for creating justice citizens. Singapore: Springer.

Higgs, J., Crisp, G., \& Letts, W. (Eds.). (2019). Education for employability: the employability agenda. Leiden: Brill Sense.

Hodges, C., Moore, S., Lockee, B., Trust, T., \& Bond, A. (2020). The difference between emergency remote teaching and online learning. EDUCAUSE Review. https://er.educause.edu/articles/2020/3/ the-difference-between-emergency-remote-teaching-and-online-learning. Accessed 29 July 2021.

Jones, C. R. (2015). Networked Learning: An educational paradigm for the age of digital networks. Dordrecht: Springer.

Kali, Y., Markauskaite, L., Goodyear, P., \& Ward, M.-H. (2011). Bridging multiple expertise in collaborative design for technology-enhanced learning. Paper presented at the Computer Supported Collaborative Learning Conference (CSCL2011), Hong Kong.

Kemmis, S. (2019). A practice sensibility: an invitation to the theory of practice architectures. Singapore: Springer Nature.

Kemmis, S., Wilkinson, J., Edwards-Groves, C., Hardy, I., Grootenboer, P., \& Bristol, L. (2014). Changing practices, changing education. Singapore: Springer Singapore.

Könings, K. D., Bovill, C., \& Woolner, P. (2017). Towards an interdisciplinary model of practice for participatory building design in education. European Journal of Education, 52(3), 306-317. https://doi. org/10.1111/ejed.12230.

Knorr Cetina, K. (1999). Epistemic cultures: how the sciences make knowledge. Cambridge, MA: Harvard University Press.

Krippendorff, K. (2006). The semantic turn: a new foundation for design. Boca Raton, FL: CRC Press.

Lamb, J., \& Ross, J. (2021). Lecture capture, social topology, and the spatial and temporal arrangements of UK universities. European Educational Research Journal, 1474904121993982. https://doi.org/ 10.1177/2F1474904121993982.

Laurillard, D. (1987). The different forms of learning in psychology and education. In J. Richardson, M. Eysenck, \& D. Warren Piper (Eds.), Student learning: Research in education and cognitive psychology (pp. 198-207). Buckingham: Open University Press.

Lave, J., \& Wenger, E. (1991). Situated learning: legitimate peripheral participation. Cambridge: Cambridge University Press.

Macgilchrist, F. (2021). Theories of postdigital heterogeneity: implications for research on education and datafication. Postdigital Science and Education. https://doi.org/10.1007/s42438-021-00232-w.

Manne, A. (2020). The universal caregiver society. https://bleedonline.net/artists/assembly-for-thefuture_lead_essay/. Accessed 29 July 2021.

Manzini, E. (2015). Design, when everybody designs: an introduction to design for social innovation. Cambridge MA: MIT Press.

Markauskaite, L., \& Goodyear, P. (2017). Epistemic fluency and professional education: innovation, knowledgeable action and actionable knowledge. Dordrecht: Springer.

Mulgan, G. (2020). Social sciences and social imagination. https://campaignforsocialscience.org.uk/ news/social-sciences-and-social-imagination/. Accessed 29 July 2021.

Nelson, H., \& Stolterman, E. (2014). The design way: intentional change in an unpredictable world (2nd ed.). Cambridge, MA: MIT Press.

Nørgård, R. T., \& Bengtsen, S. S. E. (2016). Academic citizenship beyond the campus: A call for the placeful university. Higher Education Research \& Development, 35(1), 4-16. https://doi.org/10. 1080/07294360.2015.1131669.

Nørgård, R. T., Mor, Y., \& Bengtsen, S. S. E. (2019). Networked learning in, for, and with the world. In A. Littlejohn, J. Jaldemark, E. Vrieling, \& F. Nijland (Eds.), Networked professional learning: emerging and equitable discourses for professional development (pp. 71-88). Cham: Springer.

Norman, D. (1999). Affordance, conventions and design. Interactions, 6(3), 38-43. https://doi.org/10. $1145 / 301153.301168$.

Nussbaum, M. C. (2011). Creating capabilities: the human development approach. Cambridge, MA: The Belknap Press.

Nussbaum, M. C., \& Sen, A. (Eds.). (1993). The quality of life. Oxford: Oxford University Press.

Oldham, O. (2021). Imagination infrastructure - what do we mean? https://oliviaoldham.medium.com/ imagination-infrastructure-abd96262fff6. Accessed 29 July 2021. 
Oliver, M. (2005). The problem with affordance. E-learning, 2(4). https://doi.org/10.2304/elea.2005.2.4. 402.

Puig de la Bellacasa, M. (2017). Matters of care: Speculative ethics in more than human worlds. Minneapolis, MN: University of Minnesota Press.

Rapanta, C., Botturi, L., Goodyear, P., Guárdia, L., \& Koole, M. (2020). Online university teaching during and after the covid-19 crisis: refocusing teacher presence and learning activity. Postdigital Science and Education, 2(3), 923-945. https://doi.org/10.1007/s42438-020-00155-y.

Raworth, K. (2017). Doughnut economics: seven ways to think like a 21st century economist. London: Penguin Random House.

Rietveld, E., Denys, D., \& van Westen, M. (2018). Ecological-Enactive Cognition as engaging with a field of relevant affordances: The Skilled Intentionality Framework (SIF). In A. Newen, L. De Bruin, \& S. Gallagher (Eds.), Oxford Handbook of 4E Cognition. Oxford: Oxford University Press.

Rietveld, E., \& Kiverstein, J. (2014). A rich landscape of affordances. Ecological Psychology, 26(4), 325352. https://doi.org/10.1080/10407413.2014.958035.

Ross, J. (2016). Speculative method in digital education research. Learning, Media and Technology, 42(2), 214-229. https://doi.org/10.1080/17439884.2016.1160927.

Schatzki, T. (2019). Social change in a material world. Abingdon: Routledge.

Sen, A. (2013). The ends and means of sustainability. Journal of Human Development and Capabilities, 14(1), 6-20. https://doi.org/10.1080/19452829.2012.747492.

Sinclair, C., \& Hayes, S. (2019). Between the post and the com-post: examining the postdigital 'work' of a prefix. Postdigital Science and Education, 1(1), 119-131. https://doi.org/10.1007/ s42438-018-0017-4.

Snaza, N., \& Singh, J. (2021). Introduction: Dehumanist education and the colonial university. Social Text, 39(1 (146)), 1-19. https://doi.org/10.1215/01642472-8750064.

Snir, I. (2021). Walter Benjamin in the age of post-critical pedagogy. Studies in Philosophy and Education, 40(2), 201-217. https://doi.org/10.1007/s11217-020-09749-2.

Turner, P. (2005). Affordance as context. Interacting with Computers, 17. 787-800. https://doi.org/10. 1016/j.intcom.2005.04.003.

van Dijk, L., \& Rietveld, E. (2017). Foregrounding sociomaterial practice in our understanding of affordances: the Skilled Intentionality Framework. Frontiers in Psychology, 7, 1-12. https://doi.org/10. 3389/fpsyg.2016.01969.

Willis, A.-M. (2006). Ontological designing. Design philosophy papers, 4(2), 69-92. https://doi.org/10. 2752/144871306X13966268131514. 